\title{
Molecular analysis of sourdough reveals Lactobacillus mindensis sp. nov.
}

\author{
Matthias A. Ehrmann, Martin R. A. Müller and Rudi F. Vogel \\ Lehrstuhl für Technische Mikrobiologie, Technische Universität München, \\ Weihenstephaner Steig 16, D-85350 Freising-Weihenstephan, Germany
}

Correspondence
Matthias A. Ehrmann
M.ehrmann@|rz.tu-muenche.de

\section{INTRODUCTION}

Amongst bacteria, the lactic acid bacteria (LAB) group plays the obviously most important role in human and animal nutrition and maintenance of health (Hammes \& Vogel, 1995; Herrero et al., 1996). From an ecological point of view, food fermentations represent special niches where communities of highly specialized organisms have been established. As in cereal fermentations educts cannot be subjected to heat sterilization, the occurrence of micro-organisms as well as their numbers are strictly dependent on substrates and technological parameters (Salovaara, 1998). With few exceptions, in sourdough fermentation for rye bread production lactobacilli were shown to be mainly responsible for acidification, inhibition of rye amylases, bread volume, texture and nutritional value or increased shelf life and flavour (Vogel et al., 1996, 1999). Depending on the tradition in production parameters of the sourdough, isolates were assigned to the obligately homofermentative species Lactobacillus acidophilus, Lactobacillus delbrueckii and Lactobacillus farciminis, the facultatively heterofermentative Lactobacillus alimentarius, Lactobacillus casei, Lactobacillus paralimentarius and Lactobacillus plantarum, and the heterofermentative Lactobacillus brevis, Lactobacillus buchneri, Lactobacillus fermentum, Lactobacillus fructivorans and

Published online ahead of print on 7 June 2002 as DOI 10.1099/ ijs.0.02202-0.

The EMBL accession number for the 16S rDNA sequence of $L$. mindensis DSM $14500^{\top}$ is AJ313530.
Lactobacillus sanfranciscensis. The consequent application of molecular techniques led to the identification of many new species.

Both Lactobacillus pontis and its phylogenetic relative Lactobacillus panis were described as endemic members in batters with an extended fermentation period and higher temperatures (Vogel et al., 1994; Wiese et al., 1996). The most recently described species were Lactobacillus frumenti (Müller et al., 2000) and L. paralimentarius (Cai et al., 1999).

Recently, we isolated an organism, not assignable to an hitherto known species, that occurred in small numbers along with dominating strains of $L$. sanfranciscensis in a commercial sourdough starter preparation. As this organism was also shown to persist after multiple consecutive propagations over 6 months in a bakery's sourdough, we considered it to be a relevant member of the sourdough flora. According to phenotypic and genotypic results, the purpose of the present study was to describe this Lactobacillus as a new species for which we propose the name Lactobacillus mindensis.

\section{METHODS}

Strains, medium and culture conditions. Strain TMW $1.80^{\mathrm{T}}$ was isolated from an industrial rye sourdough starter preparation (BRS). Strains TMW 1.1201, TMW 1.1199 and TMW 1.1206 originate from a bakery sourdough initiated with BRS and propagated by back-slopping (repeated cyclic reinoculation) for 6 months without additional inoculation with BRS. Samples were subjected to serial 
dilutions and plated on modified MRS medium as described by Vogel et al. (1994). Strains of L. mindensis were incubated at $30^{\circ} \mathrm{C}$. Other lactobacilli were grown on regular MRS and incubated at the temperature recommended by the respective strain collection. Solid media were incubated under a modified atmosphere $\left(\mathrm{N}_{2}: \mathrm{CO}_{2}\right.$ $90 \%: 10 \%, \mathrm{v} / \mathrm{v})$. Cultures were maintained at $-80^{\circ} \mathrm{C}$ in glycerol stocks. The purity of cultures was checked microscopically. Strains have been deposited at the DSMZ (Braunschweig, Germany), the type strain being DSM $14500^{\mathrm{T}}$.

Physiological characterization. Sugar fermentation patterns were determined by using a microtitre plate assay as described by Müller et al. (2000). The reproducibility was verified by repeated analyses. A pH-dependent change of the indicator was documented after 24, 48 and $168 \mathrm{~h}$. Only definitive turnovers were rated as positive. Additional experiments were carried out using the API $50 \mathrm{CH}$ kit (bioMérieux).

The formation of lactate isomers in fermented broth was determined enzymically using the DL-lactate test kit (Boehringer). Arginine hydrolysis was determined according to the methods described by Sharpe (1979).

Morphological characteristics. Cell morphology was studied by phase-contrast microscopy. Gram determination was performed using the KOH method of Gregersen (1978).

DNA base composition. The mol $\% \mathrm{G}+\mathrm{C}$ content of strain TMW $1.80^{\mathrm{T}}$ was determined by a HPLC analytical method. The experiments were performed by the DSMZ (Germany). They were carried out using the protocol previously described by Tamaoka \& Komagata (1984). The G $+\mathrm{C}$ content (mol\%) was determined after Mesbah et al. (1989). Wild-type lambda phage DNA was used as standard.

Cell wall. The peptidoglycan structure of the cell wall was determined by the DSMZ (Germany). The absence of teichoic acids was determined as described by Baddiley \& Davison (1961).

DNA isolation. DNA was isolated according to Marmur (1961) with some modifications. One hour before cells were harvested, penicillin G (Sigma) was added to inhibit the synthesis of cross-linking of the cell wall, and therefore to facilitate the lysis. A wet weight of $70 \mathrm{mg}$ cells was used for the DNA isolation. Following the protocol, lysis was completed within 45-90 min after the addition of lysozyme and mutanolysin. For some strains a more effective lysis was obtained by an overnight lysis at $4^{\circ} \mathrm{C}$ with a subsequent proteinase $\mathrm{K}$ treatment at $60^{\circ} \mathrm{C}$ for $1 \mathrm{~h}$, and then continuing the protocol. The purified and vacuum-dried DNA was dissolved in $2 \times \operatorname{SSC}(0.3 \mathrm{M}$ $\mathrm{NaCl}, 0.03 \mathrm{M} \mathrm{Na}_{3}$ citrate. $2 \mathrm{H}_{2} \mathrm{O}, \mathrm{pH} 7 \cdot 0$ ). This DNA preparation served for DNA-DNA hybridization experiments as well as for $16 \mathrm{~S}$ rDNA amplification. DNA used for RAPD analyses was prepared in small-scale preparations as described by Lewington et al. (1987).

RAPD-PCR. The colonies subjected to RAPD-PCR were picked randomly. PCR was carried out with the oligonucleotide primer M13V (5'-GTT TTC CCA GTC ACG AC-3'). All reactions were performed in TopYield Strips (Nunc) with oil overlay $(50 \mu \mathrm{l})$ and TECAN sealing (Tecan). The conditions for PCR amplification were as follows: $1 \mu \mathrm{l}$ genomic DNA, $5 \mu \mathrm{l} 10 \times$ reaction buffer, $5 \mathrm{mM}$ $\mathrm{MgCl}_{2}, 200 \mathrm{nM}$ of each of the four deoxynucleotides, 1.5 U Taq polymerase (all from Amersham Pharmacia Biotech) and 20 pmol primer M13V. The PCR reactions were carried out on a Hybaid OmniGene thermocycler equipped with heated lid (MWG-Biotech). The cycling program was: 3 cycles of $96^{\circ} \mathrm{C}$ for $3 \mathrm{~min}, 35^{\circ} \mathrm{C}$ for $5 \mathrm{~min}$ and $75^{\circ} \mathrm{C}$ for $5 \mathrm{~min} ; 32 \mathrm{cycles}$ of $96^{\circ} \mathrm{C}$ for $1 \mathrm{~min}, 55^{\circ} \mathrm{C}$ for $2 \mathrm{~min}$ and $75^{\circ} \mathrm{C}$ for $3 \mathrm{~min}$. Amplicons were electrophoretically separated on $1.5 \%$ TBE agarose gels.
DNA-DNA hybridization. The determination of DNA homology values was carried out using a modified procedure as described by Cardinali et al. (2000). Hydroxyapatite [HTP; $100 \mathrm{mg}$ (Bio-Rad)] was suspended in $1 \mathrm{ml} 100 \mathrm{mM}$ sodium phosphate buffer (NPB), $\mathrm{pH} 6 \cdot 7$, heated for $10 \mathrm{~min}$ at $65^{\circ} \mathrm{C}$ and centrifuged $(14000 \mathrm{~g})$ for $30 \mathrm{~s}$ at $4^{\circ} \mathrm{C}$. The HTP pellet was resuspended with the DNA solution already equilibrated at $65^{\circ} \mathrm{C}$, incubated at $65^{\circ} \mathrm{C}$ for $15 \mathrm{~min}$ and then centrifuged $(14000 \mathrm{~g})$ for $30 \mathrm{~s}$ at $4^{\circ} \mathrm{C}$. HTP-bound DNA was washed twice with $600 \mu \mathrm{l} 120 \mathrm{mM} \mathrm{NPB}$ and once with $600 \mu \mathrm{l}$ $180 \mathrm{mM}$ NPB. Finally, DNA was resuspended in $400 \mu 300 \mathrm{mM}$ potassium/sodium phosphate buffer (NPPB; $\mathrm{pH} 7 \cdot 2$ ) incubated for $15 \mathrm{~min}$ at $65^{\circ} \mathrm{C}$ and then centrifuged for $30 \mathrm{~s}$ at $14000 \mathrm{~g}$.

Desalination was carried out with NAP-5 columns (Amersham Pharmacia Biotech).

DNA was diluted in water to reach a final concentration of $10 \mathrm{ng} \mu \mathrm{l}^{-1}$ $\left(A_{260} 0 \cdot 200 \pm 5 \%\right)$. DNA was stored at $-18^{\circ} \mathrm{C}$.

For dot-blotting of DNA, samples were diluted in $0.4 \mathrm{M} \mathrm{NaOH}$ to a final concentration of $1 \mathrm{ng} \mu \mathrm{l}^{-1}$ and incubated for $30 \mathrm{~min}$ at room temperature. DNA samples (10 ng) were transferred by using a dot-blot apparatus (Stratagene) on nylon Hybaid-N + membrane (Amersham Pharmacia Biotech). Fixation of DNA on the membrane was achieved by incubation at $80^{\circ} \mathrm{C}$ for $1 \mathrm{~h}$.

For quantification, a serial dilution $(10,8,6,4,2 \mathrm{ng})$ of unlabelled DNA was dotted.

DNAs used for probes were labelled using the non-radioactive ECL random prime labelling and detection system (Amersham Pharmacia Biotech) according to the manufacturer's instructions. Prehybridization, hybridization and stringency washings $(0.5 \mathrm{M} \mathrm{NaCl})$ were carried out at $42^{\circ} \mathrm{C}$.

Membranes were exposed to a Kodak X-Omat film (Sigma-Aldrich). The spot intensity was calculated with the Image Master 2D Elite software (Amersham Pharmacia Biotech).

165 rDNA amplification and sequencing. PCR-mediated amplification of the complete $16 \mathrm{~S}$ rDNA was carried out in a Gradient Master Thermocycler (Eppendorf). All reagents if not indicated otherwise were from Amersham Pharmacia Biotech. The amplification conditions were as follows: $1 \mu \mathrm{l}$ genomic DNA, $10 \mu \mathrm{l} 10 \times$ reaction buffer, $200 \mathrm{nM}$ each of the four deoxynucleotides, $1.5 \mathrm{U}$ Taq polymerase, $20 \mathrm{pmol}$ each primer (Interactiva) (616V, 5' -AGAGTTTGATYMTGGCTCAG-3'; 630R, 5' -CAKAAAGGAGGTGATCC-3'), $\mathrm{dH}_{2} \mathrm{O}$ to a final volume of $100 \mu$ l. The PCR conditions were: $\left(94^{\circ} \mathrm{C} / 2 \mathrm{~min}\right) 1 \times,\left(94^{\circ} \mathrm{C} / 45 \mathrm{~s}, 52^{\circ} \mathrm{C} / 1 \mathrm{~min}, 72^{\circ} \mathrm{C} /\right.$ $30 \mathrm{~s}) 30 \times,\left(94^{\circ} \mathrm{C} / 1 \mathrm{~min}, 72^{\circ} \mathrm{C} / 4 \mathrm{~min}\right) 1 \times$. PCR products were purified by the QIAquick PCR purification kit (Qiagen) and were eluted with $60 \mu \mathrm{l}$ elution buffer. DNA sequences were determined by the chain-termination method (Sanger et al., 1977) using the ABI Prism Dye Terminator Cycle Sequencing Kit (Perkin Elmer) on an ABI 373 stretch sequencing system by a commercial service (SequiServe). For sequencing, the amplification primer $616 \mathrm{~V}$ together with the internal primers 609R [5'-ACT AC(CT) (AGC)GG GTA TCT AA(GT) CC-3'], 612R [5'-GTA AGG TT(CT) T(AGCT)C GCG T-3'], 607R (5'-ACG TGT GTA GCC C-3'), 606R [5'-T(AG)A CGG (GC)C(AG) GTG TGT ACA-3'] and 607V (5'-GGG CTA CAC ACG TGC-3') were used.

Phylogenetic analysis. The complete 16S rDNA sequence of L. mindensis DSM $14500^{\mathrm{T}}$ was fitted into alignments of almost complete primary structures available in public databases (Ludwig, 1995). Additional sequences were obtained from the Ribosomal Database Project (Maidak et al., 2001). Distance matrix, maximumparsimony and maximum-likelihood methods were applied for tree 
reconstructions as implemented in the ARB software package (Ludwig \& Strunk, 1997). Different datasets varying with respect to included outgroup reference sequences as well as alignment positions were analysed. To exclude highly variable regions, a filter with $50 \%$ invariance was applied.

Species-specific detection by PCR. The specific primer PmindR (5'-AAC AGT GAT CAT GTG AAG AC-3') was checked for its specificity against other bacterial $16 \mathrm{~S}$ rRNA sequences by using the probe-checking software provided in the Ribosomal Database Project (Maidak et al., 2001). PmindR was applied in combination with primer $616 \mathrm{~V}$ in the PCR assay. The amplification conditions were as follows: $1 \mu \mathrm{l}$ genomic DNA, $5 \mu \mathrm{l} 10 \times$ reaction buffer, $1 \cdot 5 \mu \mathrm{l}$ DMSO, $200 \mathrm{nM}$ each of the four deoxynucleotides, $1.5 \mathrm{U}$ Taq polymerase, 20 pmol each primer $(616 \mathrm{~V}, \mathrm{PminR})$, deionized $\mathrm{H}_{2} \mathrm{O}$ to a final volume of $50 \mu \mathrm{l}$. The PCR program used was: $\left(94^{\circ} \mathrm{C} / 2 \mathrm{~min}\right) 1 \times$, $\left(94^{\circ} \mathrm{C} / 45 \mathrm{~s}, 62 \cdot 5^{\circ} \mathrm{C} / 30 \mathrm{~s}, 72^{\circ} \mathrm{C} / 30 \mathrm{~s}\right) 30 \times$. A control PCR to check the accessibility of DNA with universal primers $616 \mathrm{~V}$ and $609 \mathrm{R}$ was performed as described previously (Garriga et al., 1998).

\section{RESULTS AND DISCUSSION}

Typical constituents found in traditional three-stage processed doughs were obligately heterofermentative species like L. sanfranciscensis, Lactobacillus brevis, L. fermentum and L. fructivorans (Stolz, 1995), amongst which L. sanfranciscensis was the numerically dominant organism (Böcker et al., 1990; Spicher \& Schröder, 1978).

The composition of the bacterial flora of the sourdough described in Methods was analysed by the use of the RAPD technique. A database of RAPD reference patterns of lactobacilli isolated from food fermentations was generated and shown to allow differentiation at the species level (Fig. 1). The total bacterial cell count in the sourdough under investigation was $10 \cdot 3 \times 10^{8}$ c.f.u. $\mathrm{g}^{-1}$, whereas the concentration of yeasts was $6 \times 10^{7}$ c.f.u. $\mathrm{g}^{-1}$.

DNAs isolated from 117 randomly selected bacterial colonies were compared to the RAPD database. According to pattern similarity we found that $61 \%$ were $L$. sanfranciscensis and $36 \%$ of strains shared identical patterns with Lactobacillus sp. TMW $1.80^{\mathrm{T}}$. The latter strain was previously isolated from an industrial sourdough starter preparation and characterized as Lactobacillus species only.

The remaining 3\% consisted of other lactic acid bacteria whose RAPD patterns could not be assigned to any Lactobacillus species available in our RAPD database (data not shown). The strains of the ' $36 \%$ ' group, TMW 1.1201, TMW 1.119, TMW 1.1206 and the previous isolate TMW $1.80^{\mathrm{T}}$, were subjected to a further taxonomic characterization.

\section{Phylogenetic analysis}

The complete sequence (1544 bp) of the 16S rRNA gene of strain TMW $1.80^{\mathrm{T}}$ was determined. It was aligned with all available sequences of low $\mathrm{G}+\mathrm{C}$ content Gram-positive organisms. The analysis placed the representative strain TMW $1.80^{\mathrm{T}}$ within the $L$. plantarum group of the

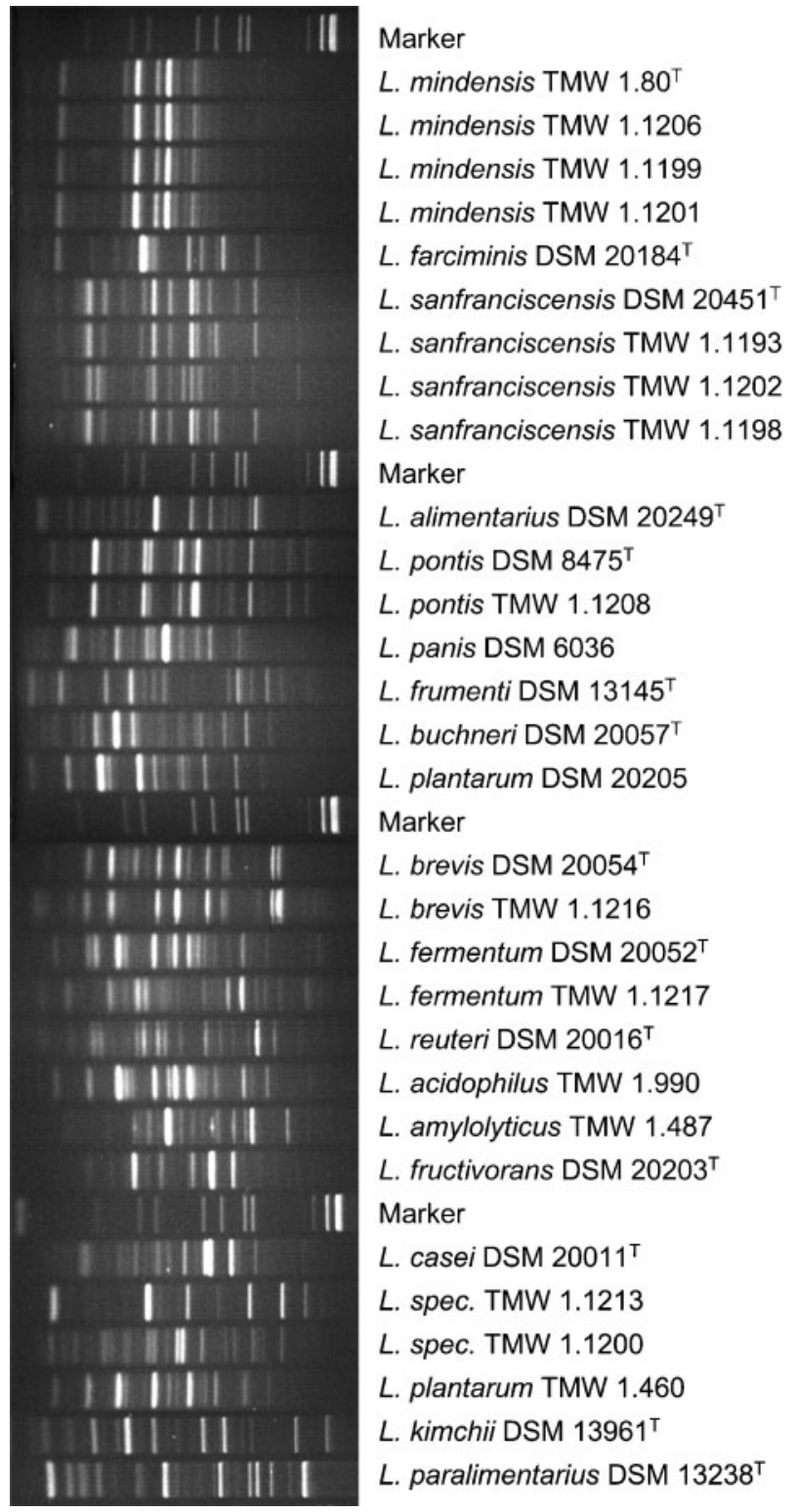

Fig. 1. RAPD patterns of various lactobacilli often described as typical organisms in sourdough fermentations.

heterogeneous L. casei group as defined by Schleifer \& Ludwig (1995). It represents a cluster of related species consisting of L. alimentarius, L. farciminis, the recently described L. paralimentarius (Cai et al., 1999) and L. kimchii (Yoon et al., 2000). Except for L. kimchii, all the abovementioned species have already been isolated from sourdoughs. The closest relatives were L. kimchii (98.7\%), L. alimentarius $(97 \cdot 5 \%)$ and L. paralimentarius $(97 \cdot 2 \%)$. The phylogenetic position is shown in Fig. 2. Positions determined by the parsimony algorithm were identical with those obtained with the maximum-likelihood approach. Minor differences in branching points were found by application of the neighbour-joining method (data not shown). 


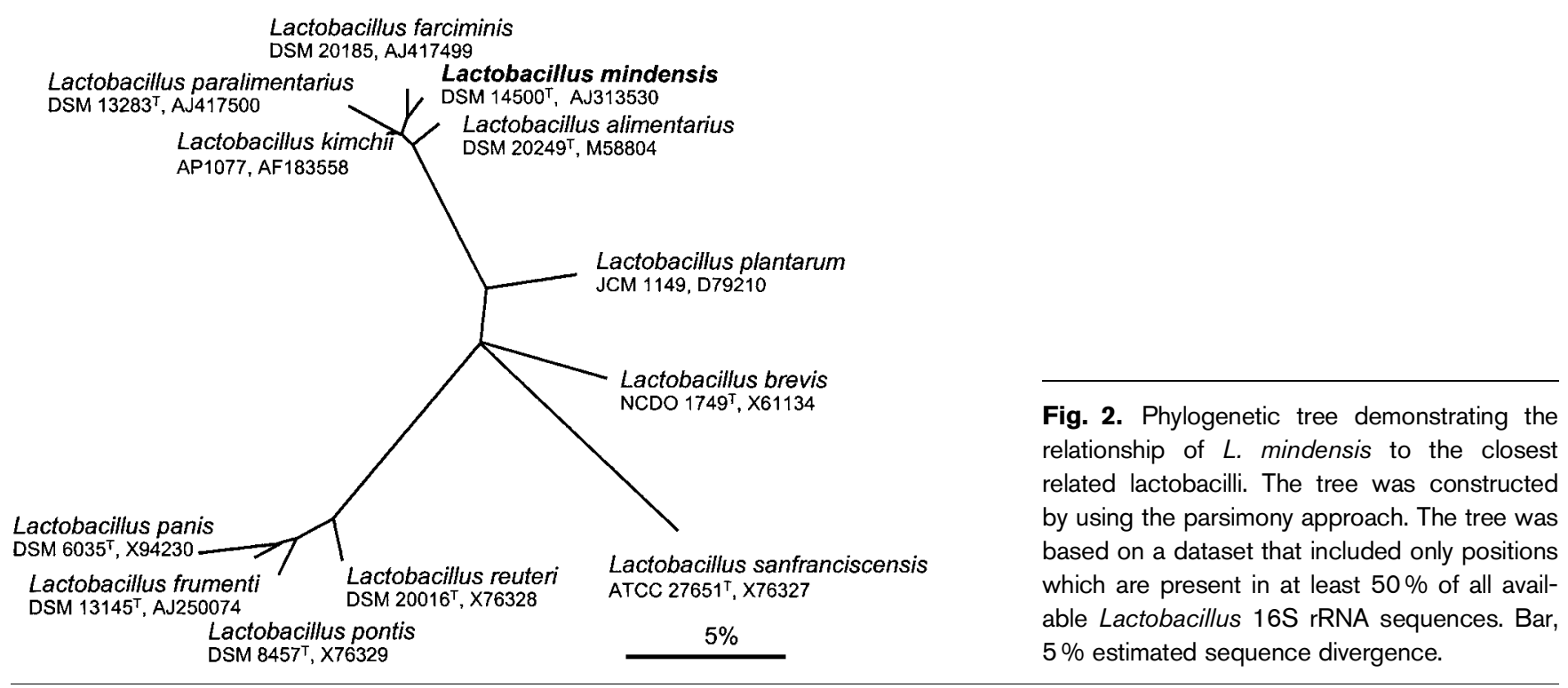

The $\mathrm{G}+\mathrm{C}$ content of the $16 \mathrm{~S} \mathrm{rDNA}$ was $51 \cdot 2 \mathrm{~mol} \%$.

The DNA-DNA hybridization studies were performed according to the method of Cardinali et al. (2000). For each hybridization experiment, a calibration by serial dilutions of homologous DNA was applied on the same membrane. The relationship between spot intensity and amount of blotted DNA was highly linear with correlation values $\left(r^{2}\right)$ equal or over $95 \%$ (data not shown).

Whereas DNA-DNA relatedness between strains TMW $1.80^{\mathrm{T}}$, TMW 1201, TMW 1.1199 and TMW 1206 of L. mindensis revealed by DNA-DNA hybridization experiments was greater than $85 \%$, hybridizations of these strains against DNA from all relevant type strains showed values below $30 \%$ (Fig. 3).
As these data revealed a phylogenetically homogeneous group of strains that is separate from other known species, we propose a new species, $L$. mindensis. The type strain is TMW $1.80^{\mathrm{T}}$ deposited at the DSMZ as L. mindensis DSM $14500^{\mathrm{T}}$.

\section{Colony and cell morphology}

Colonies of L. mindensis DSM $14500^{\mathrm{T}}$ appeared white with a regular sharp edge and after 3 days of growth they were $1 \mathrm{~mm}$ in diameter. Colonies older than 3 days appeared frayed at the edges.

Cells were non-spore-forming, non-motile rods that occurred singly or in pairs, seldom in chains. Under the phase-contrast microscope, cells grown in liquid culture appeared as straight rods measuring $0 \cdot 3-0 \cdot 7 \times 3-5 \mu \mathrm{m}$ (in

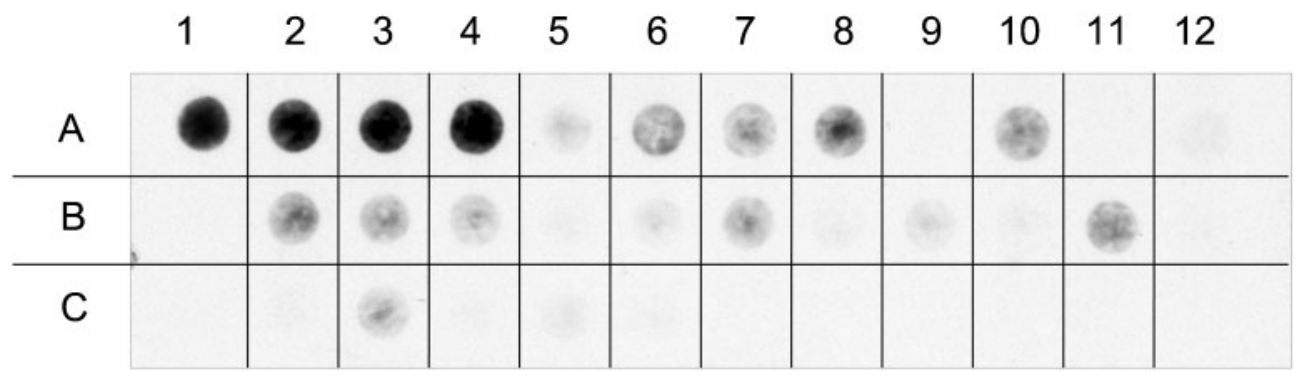

Fig. 3. DNA-DNA hybridization experiment between DNA of $L$. mindensis and other lactobacilli. Genomic DNA of L. mindensis TMW 1.1201 was used as a probe and $10 \mathrm{ng}$ DNA of the following strains was blotted. Row A: 1, L. mindensis TMW 1.80'; 2, L. mindensis TMW 1.1201; 3, L. mindensis TMW 1.1199; 4, L. mindensis TMW 1.1206; 5, L. sanfranciscensis TMW 1.1203; 6, L. farciminis DSM 20184 ${ }^{\top} ; 7$, L. alimentarius DSM 20249 ${ }^{\top} ; 8$, L. sanfranciscensis DSM $20451^{\top}$; 9, L. pontis DSM 8475'; 10, Lactobacillus oris DSM 4864; 11, L. panis DSM 6035; 12, L. panis DSM 6036. Row B: 1, L. frumenti DSM 13143; 2, L. frumenti DSM $13145^{\top} ; 3$, L. buchneri DSM $20057^{\top} ; 4$, Lactobacillus kefiri DSM $20587^{\top}$; 5, Lactobacillus malefermentans DSM 2017; 6, L. plantarum DSM 20174 ${ }^{\top} ; 7$, L. brevis DSM 20451 ${ }^{\top} ; 8^{8}$, L. fermentum DSM 20052 ${ }^{\top}$; 9, Lactobacillus lindneri DSM 20690 ${ }^{\top} ; 10$, Lactobacillus vaginalis LMG 1289; 11, Lactobacillus hilgardii DSM 20176; 12, Lactobacillus parabuchneri DSM 5707 ${ }^{\top}$. Row C: 1, Lactobacillus amylolyticus DSM $11664^{\top} ; 2$, L. pontis TMW 1.675; 3, L. plantarum TMW 1.535. 

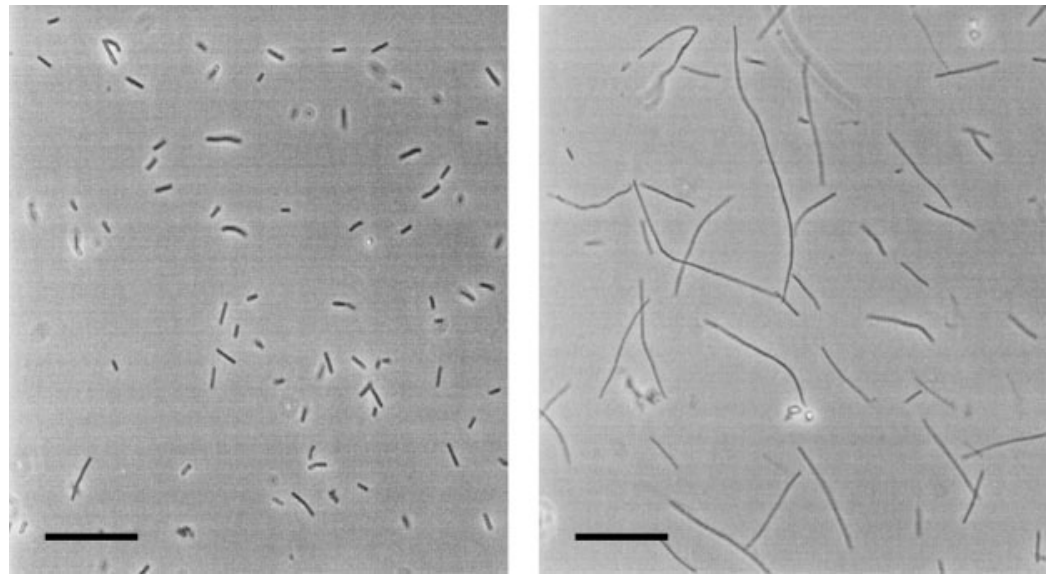

Fig. 4. Phase-contrast micrographs of cells of Lactobacillus mindensis DSM $14500^{\top}$. Cells were grown on MRS. Left-hand panel, cells grown in liquid culture; right-hand panel, cells grown on solid medium. Bar, $10 \mu \mathrm{m}$.

mid- to late-exponential growth phase). Cells on solid media were observed to elongate filamentously with a length between 5 and $20 \mu \mathrm{m}$ (Fig. 4). The $\mathrm{KOH}$ test indicated a Gram-positive behaviour.

\section{Physiological and biochemical properties}

The sugar fermentation patterns and further physiological and biochemical characteristics of $L$. mindensis strains and the reference organisms are listed in Table 1. Lactate is produced in a ratio of $96 \%$ L-lactate to $4 \% \mathrm{D}$-lactate. Gas was not produced from glucose. Acid was produced from glucose, fructose, mannose, aesculin, salicin and cellobiose by all strains tested. Only weak fermentation of maltose was detected. Strain TMW 1.1206 did not ferment amygdalin.

The $\mathrm{G}+\mathrm{C}$ content of genomic DNA is $37.5 \mathrm{~mol} \%\left(T_{\mathrm{m}}\right)$. Analysis of the cell wall in strain TMW $1.80^{\mathrm{T}}$ revealed the presence of lysine and aspartic acid, which indicates the Lys-D-Asp peptidoglycan type.

\section{Design of a species-specific PCR detection assay}

A diagnostic sequence was identified within the 16S rRNA gene (see Table 2) that allows the identification of strains of L. mindensis and differentiation thereof from other relevant lactobacilli when used as target site in a PCR assay (Fig. 5). Primer PmindR, in combination with the $16 \mathrm{~S}$ rDNA universal primer $616 \mathrm{~V}$, generated a $226 \mathrm{bp}$ fragment. No cross-reaction was detected for DNA of other lactobacilli. Accessibility of DNA preparations for amplification was successfully controlled by a simultaneous amplification with $16 \mathrm{~S}$ rDNA specific universal primers.

The RAPD fingerprint identity of all four strains (TMW $\left.1.80^{\mathrm{T}}, 1.1199,1.1201,1.1206\right)$, and their DNA-DNA homology values above $80 \%$ with each other and values less than $30 \%$ to other species, provided enough phylogenetic data to propose a separate species status.

The $\mathrm{G}+\mathrm{C}$ content of $37.5 \mathrm{~mol} \%$ is within the range of the L. plantarum group (34-46\%), and the peptidoglycan type (L-Lys-D-Asp) fell into line with the majority of lactobacilli.

Taxonomic significance is provided by the lack of fermentation of galactose, arbutin, lactose and trehalose, which allows differentiation from its closest relatives. One difference to L. paralimentarius is the lack of ability to ferment ribose, arbutin, sucrose and trehalose. The limited fermentation spectrum is a typical trait as it can also be observed in other sourdough lactobacilli. The moderate fermentation of maltose also observed in some strains of L. paralimentarius (Cai et al., 1999) seems to be at first unfavourable for this environment, but may explain the observed coexistence with L. sanfranciscensis, which was shown to possess a highly optimized maltose metabolism resulting in production of glucose (Stolz, 1995; Ehrmann \& Vogel, 1998).

The increased occurrence of L. mindensis in the investigated sourdough may be caused by specific process parameters used in the bakery. Its effect on dough quality and aroma was not investigated in this study.

\section{Description of Lactobacillus mindensis sp. nov.}

Lactobacillus mindensis (min.den'sis. N.L. adj. mindensis pertaining to the city of Minden, Germany, from where the first strain of this species was isolated).

Cells are Gram-positive, non-motile, non-spore-forming rods $(0 \cdot 9-5 \mu \mathrm{m})$, occurring singly, in pairs or in chains. Colonies are usually small $(2 \mathrm{~mm})$, smooth, low convex and flat with a white colour on MRS agar. Cells are catalasenegative and homofermentative. Growth occurs at $15-30{ }^{\circ} \mathrm{C}$ but not above. Growth optimum is at $\mathrm{pH} 4 \cdot 6-5 \cdot 2$; no growth at or above $\mathrm{pH} 6 \cdot 5$. Acid is produced from glucose, maltose, fructose, mannose, $N$-acetylglucosamine, cellobiose and salicin. Some strains produce acid from amygdalin. Neither acid nor gas is produced from arabinose, dextrin, galactose, lactose, mannitol, melezitose, melibiose, raffinose, rhamnose, ribose, sucrose, sorbitol, trehalose or xylose. Arginine decarboxylase was not detected. Urease and $\mathrm{H}_{2} \mathrm{~S}$ are not produced. Nitrate is not reduced to nitrite. 
Table 1. Physiological and biochemical characteristics of L. mindensis and selected reference organisms

1, L. mindensis DSM $14500^{\mathrm{T}}$ TMW $1.80^{\mathrm{T}}$; 2, L. frumenti DSM $13145^{\mathrm{T}} ; 3$, L. kimchii JCM $10707^{\mathrm{T}}$; 4, L. farciminis $\mathrm{LMG} 9200^{\mathrm{T}}$; 5 , L. alimentarius JCM $1095^{\mathrm{T}}$; 6, L. paralimentarius JCM $10415^{\mathrm{T}} ; 7$, L. sanfranscicensis ATCC $27651^{\mathrm{T}}$. ND, Not determined; -, negative reaction; +, positive reaction; $\mathrm{w}$, weak reaction.

\begin{tabular}{|c|c|c|c|c|c|c|c|}
\hline Characteristic(s) & 1 & $2^{\star}$ & $3 \dagger$ & $4 \ddagger$ & $5 \S$ & $6 \S$ & 711 \\
\hline $\mathrm{NH}_{3}$ from arginine & - & + & - & ND & - & ND & - \\
\hline Peptidoglycan type & L-Lys-D-Asp & L-Lys-D-Asp & L-Lys-D-Asp & L-Lys-D-Asp & L-Lys-D-Asp & ND & L-Lys-Ala \\
\hline DNA G $+\mathrm{C}$ content $(\mathrm{mol} \%)$ & $37 \cdot 5 \pm 0 \cdot 2$ & $43 \cdot 3 \pm 0 \cdot 2$ & $35 \cdot 0$ & $34-36$ & $36-37$ & $37 \cdot 2-38$ & $36-38$ \\
\hline \multicolumn{8}{|l|}{ Acid production from: } \\
\hline Ribose & - & + & + & - & + & + & + \\
\hline DL-Xylose & - & - & + & - & + & - & - \\
\hline Galactose & - & + & $\mathrm{w}$ & + & + & - & +- \\
\hline Glucose & + & + & + & + & + & + & + \\
\hline Fructose & + & + & + & + & + & + & - \\
\hline Amygdalin & + & + & + & + & + & + & - \\
\hline Arbutin & - & + & + & ND & + & + & - \\
\hline Aesculin & + & + & + & + & + & + & - \\
\hline Salicin & + & + & + & + & + & + & - \\
\hline Cellobiose & + & + & + & + & + & + & + \\
\hline Maltose & $\mathrm{w}$ & + & + & + & + & $+1-$ & + \\
\hline Lactose & - & + & - & + & - & - & - \\
\hline Melibiose & - & + & ND & - & - & - & - \\
\hline Sucrose & - & + & + & + & + & + & - \\
\hline Trehalose & - & + & + & + & + & + & - \\
\hline Melezitose & - & - & + & - & - & - & - \\
\hline
\end{tabular}

${ }^{\star}$ Data from Müller et al. (2000).

tData from Yoon et al. (2000).

‡Data from Kandler \& Weiss (1986).

$\S$ Data from Cai et al. (1999).

IIData from Vogel et al. (1994); Stolz (1995).

Table 2. Diagnostic sequence signatures in the $16 \mathrm{~S}$ rRNA to differentiate $L$. mindensis from its closest relatives

The sequence used for the specific PCR (primer PmindR) is underlined.

\begin{tabular}{|lc|}
\hline Species & Sequence $\left(\mathbf{5}^{\prime} \rightarrow \mathbf{3}^{\prime}\right)$ \\
\hline L. mindensis & CAACAGTCTTCACATGATCACTGTTTAA \\
L. kimchii & CAACTTAGATCACATGATCTTTGTTTAA \\
L. farciminis & CAACTACTTTCACATGATCGTAGCTTGA \\
L. alimentarius & CAACATTAAACACATNTTNTTTGTTTAA \\
L. paralimentarius & CAACTTAGATCACATGATCTTTGTTTAA \\
\hline
\end{tabular}

All strains produce mainly L-lactate (4\% D-lactate and $96 \%$ L-lactate). The peptidoglycan is of the lysine-D-isoasparagine (L-Lys-D-Asp) type and the cell wall does not contain teichoic acid. The DNA G $+\mathrm{C}$ content is $37.5 \mathrm{~mol} \%$ $\left(T_{\mathrm{m}}\right)$. Strains were isolated from commercial sourdough starter preparations and from bakery's sourdough after continuous propagations for long periods. The type strain is DSM $14500^{\mathrm{T}}$ (= LMG $21508^{\mathrm{T}}$ ).

\section{ACKNOWLEDGEMENTS}

This work was supported by a grant from the European Union (FAIR project: CT 96 1126). We thank Dr Wolfgang Ludwig for 




Fig. 5. Identification of $L$. mindensis by a specific PCR approach. For the species-specific PCR, primers PmindR and 616V were used, and for control PCR, primers 616V and 609R were used. Specific and control PCRs were performed separately, but run in a single lane. Lanes: 1 and 12, $100 \mathrm{bp}$ ladder (molecular mass standard); 2, L. frumenti; 3, L. sanfranciscensis; 4, L. farciminis; 5, L. alimentarius; 6, L. kimchii; 7, L. paralimentarius; 8, L. mindensis TMW 1.1201; 9, L. mindensis TMW 1.1199; 10, L. mindensis TMW 1.1206; 11, L. mindensis DSM $14500^{\top}$.

the phylogenetic calculations and the reconstruction of the phylogenetic tree. We also wish to thank Monika Hadek for technical assistance.

\section{REFERENCES}

Baddiley, J. \& Davison, A. L. (1961). The occurrence and location of teichoic acid in lactobacilli. J Gen Microbiol 24, 295-299.

Böcker, G., Vogel, R. F. \& Hammes, W. P. (1990). Lactobacillus sanfrancisco als stabiles Element in einem Reinzucht-SauerteigPräparat. Getreide Mehl Brot 44, 269-274.

Cai, Y., Okada, H., Mori, H., Benno, Y. \& Nakase, T. (1999). Lactobacillus paralimentarius sp. nov., isolated from sourdough. Int J Syst Evol Microbiol 49, 1451-1455.

Cardinali, G., Liti, G. \& Martini, A. (2000). Non-radioactive dot-blot DNA reassociation for unequivocal yeast identification. Int J Syst Evol Microbiol 50, 931-936.

Ehrmann, M. A. \& Vogel, R. F. (1998). Maltose metabolism of Lactobacillus sanfranciscensis: cloning and heterologous expression of the key enzymes, maltose phosphorylase and phosphoglucomutase. FEMS Microbiol Lett 169, 81-86.

Garriga, M., Ehrmann, M. A., Arnau, J., Hugas, M. \& Vogel, R. F. (1998). Carnimonas nigrificans gen. nov., sp. nov., a bacterial causative agent for black spots formation on cured meat products. Int J Syst Bacteriol 48, 677-686.

Gregersen, T. (1978). Rapid method for distinction of Gramnegative from Gram-positive bacteria. Eur J Appl Microbiol Biotechnol 5, 123-127.

Hammes, W. P. \& Vogel, R. F. (1995). The genus Lactobacillus. In The Genera of Lactic Acid Bacteria, pp. 19-54. Edited by B. J. B. Wood \& W. Holzapfel. Glasgow: Blackie Academic \& Professional.

Herrero, M., Mayo, B., González, B. \& Suárez, J. E. (1996). Evaluation of technologically important traits in lactic acid bacteria isolated from spontaneous fermentations. J Appl Bacteriol 81, 565-570.
Kandler, O. \& Weiss, N. (1986). The genus Lactobacillus. In Bergey's Manual of Systematic Bacteriology, vol. 2, pp. 1208-1234. Edited by P. H. A. Sneath, N. S. Mair, M. E. Sharpe \& J. G. Holt. Baltimore: Williams \& Wilkins.

Lewington, J., Greenaway, S. P. \& Spillane, G. J. (1987). Rapid small scale preparation of bacterial genomic DNA, suitable for cloning and hybridization analysis. Lett Appl Microbiol 5, 51-53.

Ludwig, W. (1995). Sequence databases. In Molecular Microbial Ecology Manual, pp. 3.3.5.1-22. Edited by A. D. L. Akkermans, J. D. van Elsas \& F. J. de Bruijn. Amsterdam: Kluwer.

Ludwig, W. \& Strunk, O. (1997). ARB: a software environment for sequence data. http://www.mikro.biologie.tu-muenchen.de/pub/ARB/ documentation/

Maidak, B. L., Cole, J. R., Lilburn, T. G. \& 7 other authors (2001). The RDP-II (Ribosomal Database Project). Nucleic Acids Res 29, 173-174.

Marmur, J. (1961). A procedure for the isolation of deoxyribonucleic acid from microorganisms. J Mol Biol 3, 208-218.

Mesbah, M., Premachandran, U. \& Whitman, W. B. (1989). Precise measurement of the $\mathrm{G}+\mathrm{C}$ content of deoxyribonucleic acid by highperformance liquid chromatography. Int J Syst Bacteriol 39, 159-167.

Müller, M. R. A., Ehrmann, M. A. \& Vogel, R. F. (2000). Lactobacillus frumenti sp. nov., a new lactic acid bacterium isolated from rye-bran fermentations with a long fermentation period. Int J Syst Evol Microbiol 50, 2127-2133.

Salovaara, H. (1998). Lactic acid bacteria in cereal products. In Lactic Acid Bacteria - Technology and Health Effects, 2nd edn, pp. 115-138. Edited by S. Salminen \& A. Von Wright. New York: Marcel Dekker.

Sanger, F., Nicklen, S. \& Coulson, A. (1977). DNA sequencing with chain-terminating inhibitors. Proc Natl Acad Sci U S A 74, 5463-5467.

Schleifer, K. H. \& Ludwig, W. (1995). Phylogeny of genus Lactobacillus and related genera. Syst Appl Microbiol 18, 461-467.

Sharpe, M. E. (1979). Identification of lactic acid bacteria. In Identification Methods for Microbiologists (Technical Series 14), pp. 233-259. Edited by F. A. Skinner \& D. W. Lovelock. London: Academic Press.

Spicher, G. \& Schröder, R. (1978). Die Mikroflora des Sauerteiges, VI. Untersuchungen über die Art der in "Reinzuchtsauern" anzutreffenden Milchsäurebakterien (Genus LactobacillusBeijerink). Z Lebensm-Unters-Forsch 167, 342-354.

Stolz, P. (1995). Untersuchungen des Maltosemetabolismus von Lactobazillen aus Sauerteig. Stuttgart: Ulrich Grauer.

Tamaoka, J. \& Komagata, K. (1984). Determination of DNA base composition by reversed-phase high-performance liquid chromatography. FEMS Microbiol Lett 25, 125-128.

Vogel, R. F., Böcker, G., Stolz, P. \& 7 other authors (1994). Identification of lactobacilli from sourdough and description of Lactobacillus pontis sp. nov. Int J Syst Bacteriol 44, 223-229.

Vogel, R. F., Müller, M., Stolz, P. \& Ehrmann, M. (1996). Ecology in sourdoughs produced by traditional and modern technologies. Adv Food Sci (CMTL) 18, 152-159.

Vogel, R. F., Knorr, R., Müller, R. A., Steudel, U., Gänzle, M. G. \& Ehrmann, M. A. (1999). Non-dairy lactic fermentations: the cereal world. Antonie van Leeuwenhoek 76, 403-411.

Wiese, B. G., Strohmar, W., Rainey, F. A. \& Diekmann, H. (1996). Lactobacillus panis sp. nov., from sourdough with a long fermentation period. Int $J$ Syst Bacteriol 46, 449-453.

Yoon, J.-H., Kang, S.-S., Mheen, T.-I. \& 7 other authors (2000). Lactobacillus kimchii sp., nov., a new species from kimchii. Int J Syst Evol Microbiol 50, 1789-1795. 